\title{
Implementasi Web Service Pada Sistem Informasi Geografis (SIG) Peta Sebaran Data Covid-19 Berbasis Mobile Apps
}

\author{
Fathul Hudoyo ${ }^{* 1}$, Fauziah ${ }^{2}$, Andrianingsih Andrianingsih ${ }^{3}$ \\ ${ }^{1,2}$ Universitas Nasional; Jl. Sawo Manila No.61, RT.14/RW.7, Pejaten Bar, Kec. Ps. Minggu, \\ Kota Jakarta Selatan, Daerah Khusus Ibukota Jakarta 12520, (021) 7806700 \\ ${ }^{3}$ Jurusan Sistem Informasi, FTKI Sistem Informasi, Pejaten \\ e-mail: *1 fathulhudoyo@gmail.com, ${ }^{2}$ fauziah@ civitas.unas.ac.id, ${ }^{3}$ \\ andrianingsih@civitas.unas.ac.id
}

\begin{abstract}
Abstrak
Sistem informasi geografis adalah sistem informasi yang berbasis kerja komputer yang memasukkan, mengelola, memanipulasi, dan menganalisis data, serta memberikan deskripsi dan menghasilkan data bereferensi geografis. Dengan menggunakan Sistem Informasi Geografis maka diharapkan akan lebih mudah bagi para masyarakat indonesia untuk mengetahui lokasi atau provinsi mana saja yang paling banyak terdampak covid- 19. Menggunakan Sistem Informasi Geografis (SIG) untuk menyajikan data dan informasi dalam bentuk peta, yang bisa digunakan sebagai alat bantu saat mengambil sebuah keputusan. Penelitian menggunakan teknologi layanan web untuk mengumpulkan data dan mengintegrasikan layanan dari berbagai sumber. Protokol dan arsitektur web service yang digunakan adalah (REST), dengan pertukaran data independen menggunakan format JSON. Aplikasi (GIS) nantinya nantinya diuji dengan metode pengujian black box, kuesioner dan automation testing. Berdasarkan hasil pengujian yang telah di lakukan oleh peneliti maka di dapat hasil dari pengujian sistem yang ada dengan menggunakan metode black box dan automation testing, aplikasi berjalan seperti seharusnya dan di validasi dengan menggunakan data kuesioner kepuasan pengguna terhadap aplikasi yang telah di buat.
\end{abstract}

Kata kunci-Sistem Informasi Geografis, Covid-19, Google Maps, Implementasi Layanan Web

\begin{abstract}
Geographic information system is an information system based on computer work that enters, manages, manipulates, and analyzes data, as well as provides descriptions and generates geographically referenced data. By using the Geographic Information System, it is hoped that it will be easier for the people of Indonesia to find out which locations or provinces are most affected by COVID-19. Using the Geographic Information System (GIS) to present data and information in the form of maps, which can be used as a tool help when making a decision. Research uses web service technologies to collect data and integrate services from multiple sources. The protocol and web service architecture used is (REST), with independent data exchange using JSON format. Applications (GIS) will later be tested using black box testing methods, questionnaires and automation testing. Based on the results of the tests that have been carried out by the researchers, the results of the existing system testing using the black box method and automation testing, the application runs as it should and is validated using user satisfaction questionnaire data for the application that has been made.
\end{abstract}

Keywords - Geographical Information System, Covid-19, Google Maps, Implementation Of Web Service 


\section{PENDAHULUAN}

Covid- 19 ataupun penyakit menular Coronavirus merupakan penyakit menular yang diakibatkan oleh Sindrom Pernafasan Akut Coronavirus 2(SARS- CoV- 2). Penyakit ini berawal saat ditemui di Wuhan pada tahun 2019 [1]. Peristiwa penularan penyakit yang diakibatkan oleh virus corona varian baru yang disebut SARS- CoV- 2, yang semula merupakan virus varian baru yang disebut 2019- nCov [2]. Wabah yang diakibatkan oleh organisme berukuran 80- 150 nanometer dapat menyebabkan manusia serta ekonomi dunia hampir berhenti berfungsi [3].

Melalui pemanfaatan perkembangan ilmu pengetahuan dan teknologi, informasi tentang coronavirus serta penyebaran penyakit ini bisa diketahui dengan cepat dan akurat. Upaya pemerintah Indonesia untuk memberikan pengetahuan kepada masyarakat tentang penyebaran coronavirus sudah dilaksanakan di halaman websitenya pemerintah [4].

Coronavirus merupakan sesuatu golongan virus yang mampu mengakibatkan penyakit terhadap binatang ataupun manusia. Sebagian varian virus corona sudah diketahui bisa mengakibatkan peradangan saluran pernapasan pada seseorang, diawali batuk serta pilek bahkan infeksi saluran pernapasan yang lebih serius seperti Middle East Respiratory Syndrome (MERS) dan Severe Acute Respiratory Syndrome (SARS). Virus corona varian baru telah diketahui sebagai penyebab COVID- 19 [5].

Akan tetapi, agar bisa dipakai oleh masyarakat dibutuhkannya interface yang lebih interaktif yaitu interface yang berbasis mobile. Platform yang tidak sama perlu saling berhubungan, dan untuk mengatasi masalah informasi antara aplikasi berdasarkan Web dan mobile, teknologi Web Service bisa digunakan.

Aplikasi mobile merupakan aplikasi perangkat lunak yang berjalan dalam sebuah perangkat bergerak (smartphone, tablet, iPod, dll) dan terdapatnya sistem operasi yang mendukung perangkat lunak independen [6].

Web services adalah sistem fitur lunak yang tersusun dari gugus fungsi ataupun methods yang tersembunyi pada suatu server serta bisa dipanggil oleh klien. Dengan web services layanan serta aplikasi bisa dipakai kembali, serta adanya kemungkinan terbentuknya alterasi data antar program yang tidak sama. Teknologi web services sudah digunakan pada bidang Kesehatan [7].

Penelitian ini akan dilaksanakan manipulasi dan pencampuran data dari bermacam sumber dalam sebuah application programming interface (API) yang berupa bentuk JSON. Lalu, data itu divisualisasikan pada aplikasi sistem informasi geografis (SIG) berbasis mobile apps melalui penggunaan google maps dan di buat menggunakan framework react native.

React Native adalah framework open source dari facebook yang dibentuk untuk membangun aplikasi mobile dengan menggunakan javascript. Dengan kata lain, react native memungkinkan untuk para developer web untuk membuat aplikasi mobile yang mirip seperti aplikasi native. React native juga membuat pembuatan ini lebih mudah karena sebagian besar kode yang dibuat atau dituliskan dapat dipakai pada multiplatform, hal tersebut dikarenakan react native bersifat 9 multiplatform sehingga dapat memudahkan dalam pembuatan atau pengembangan aplikasi secara bersamaan untuk android maupun iOS [8].

Sistem informasi geografis ialah sistem berplatform komputer bermaksud menaruh serta memproses informasi geografis. GIS didesain buat mengakulasi, menyimpan, serta menganalisa objek serta kejadian, di mana wilayah geografis sebagai fitur penting ataupun kunci buat dianalisis [9].

Google Maps merupakan free service yang tersedia pada Google dan sangat terkenal. Google Maps ialah peta dunia, kita bisa menggunakannya untuk menyaksikan suatu area. Sehingga, Google Maps adalah peta yang bisa disaksikan memakai pencarian atau browser. Kita bisa membubuhkan fungsi Google Maps ke jaringan atau blog yang kita buat, berbayar atau

Fathul, et., al [Implementasi Web Service Pada Sistem Informasi Geografis (SIG) Peta Sebaran Data Covid-19 Berbasis Mobile Apps] 
gratis, bahkan memakai Google Maps API. Google Maps API merupakan pustaka JavaScript. [10]

Dengan adanya pengembangan aplikasi sistem informasi geografi pada kasus COVID-19 ini yang berbasis mobile apps, diharapkan nantinya masyarakat mengetahui persebaran COVID19 dan dapat meningkatkan kewaspadaan diri dan lingkungan.

\section{METODE PENELITIAN}

Penelitian sistem informasi geografis (SIG) untuk pemetaan penyebaran penyakit covid 19 memakai google maps berbasis mobile apps memiliki beberapa metodologi penelitian yang telah didapatkan dari hasil mengumpulkan informasi atau data dan melaksanakan investigasi pada data yang sudah didapat dan pada bab kali ini penulis akan menjelaskan mengenai metode pada penelitian ini antara lain sebagai berikut.

\subsection{Perancangan dan Arsitektur Sistem}

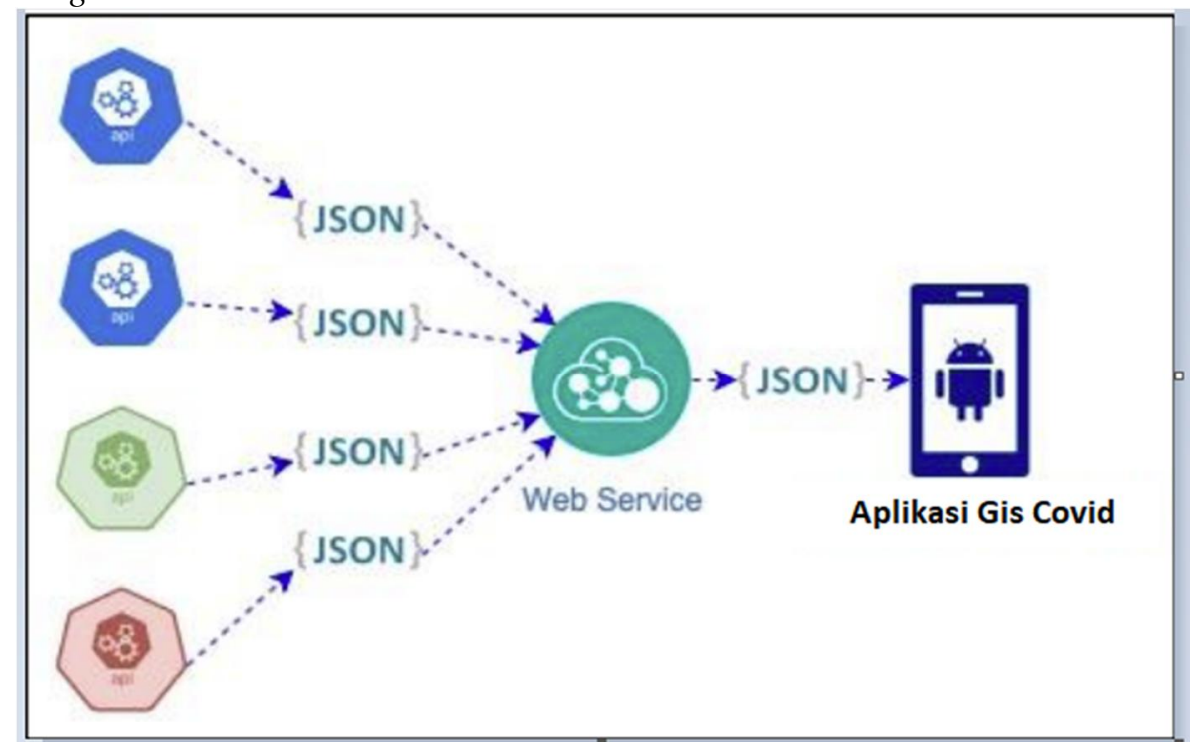

Gambar 1. Arsitektur Sistem Informasi Geografi

Arsitektur sistem yang akan dibentuk bisa disaksikan pada Gambar 1. Semua API tersebut digabungkan pada sebuah web service kemudian di visualisasikan pada bentuk aplikasi Mobile apps. Setiap sumber yang diambil nantinya memiliki fungsi dan peran sendiri data di ambil dari bermacam sumber application programming interface (API) yang berbeda. Dan berikut ada contoh gambar 2 respon api yang nantinya akan penulis gunakan sebagai bagian dari sumber data resiko tertular covid 19. macam- macam resiko yang akan di tambilkan antara lain sebagai berikut:

- Resiko tidak ada (zona hijau)

- Resiko rendah (zona kuning)

- Resiko sedang (zona oren)

- Resiko tinggi (zona merah)

Yang berada di wilayah tersebut. Data tersebut nantinya akan saya gabungkan dengan beberapa data yang lain sehingga menjadi lebih mudah untuk di visualisaikannya. Berikut adalah contoh gabungan data json pada gambar 3 yang datanya sudah di gabungkan dengan data

Fathul, et., al [Implementasi Web Service Pada Sistem Informasi Geografis (SIG) Peta Sebaran Data Covid-19 Berbasis Mobile Apps] 
pada gambar 2. Dan berikut tampilan visual User Interface (UI) pada gambar 4 yang telah di gabungkan dengan beberapa API.

Api ialah sebutan singkat dari Application Programming Interface sebuah antarmuka yang dibentuk oleh developer sistem sehingga beberapa ataupun seluruh fungsi sistem bisa diakses secara terprogram. Representational State Transfer (REST) adalah gaya arsitektur pengembangan API yang memakai Hypertext Transfer Protocol (HTTP) untuk komunikasi data. Penelitian ini menerapkan REST saat mengembangkan API sebagai back end sistem informasi pasien di klinik perawatan kulit. API memakai Javascript Object Notation( JSON) sebagai format standar untuk komunikasi data dan JSON Web Token( JWT) sebagai pengembangan kode otentikasi pengguna [11].

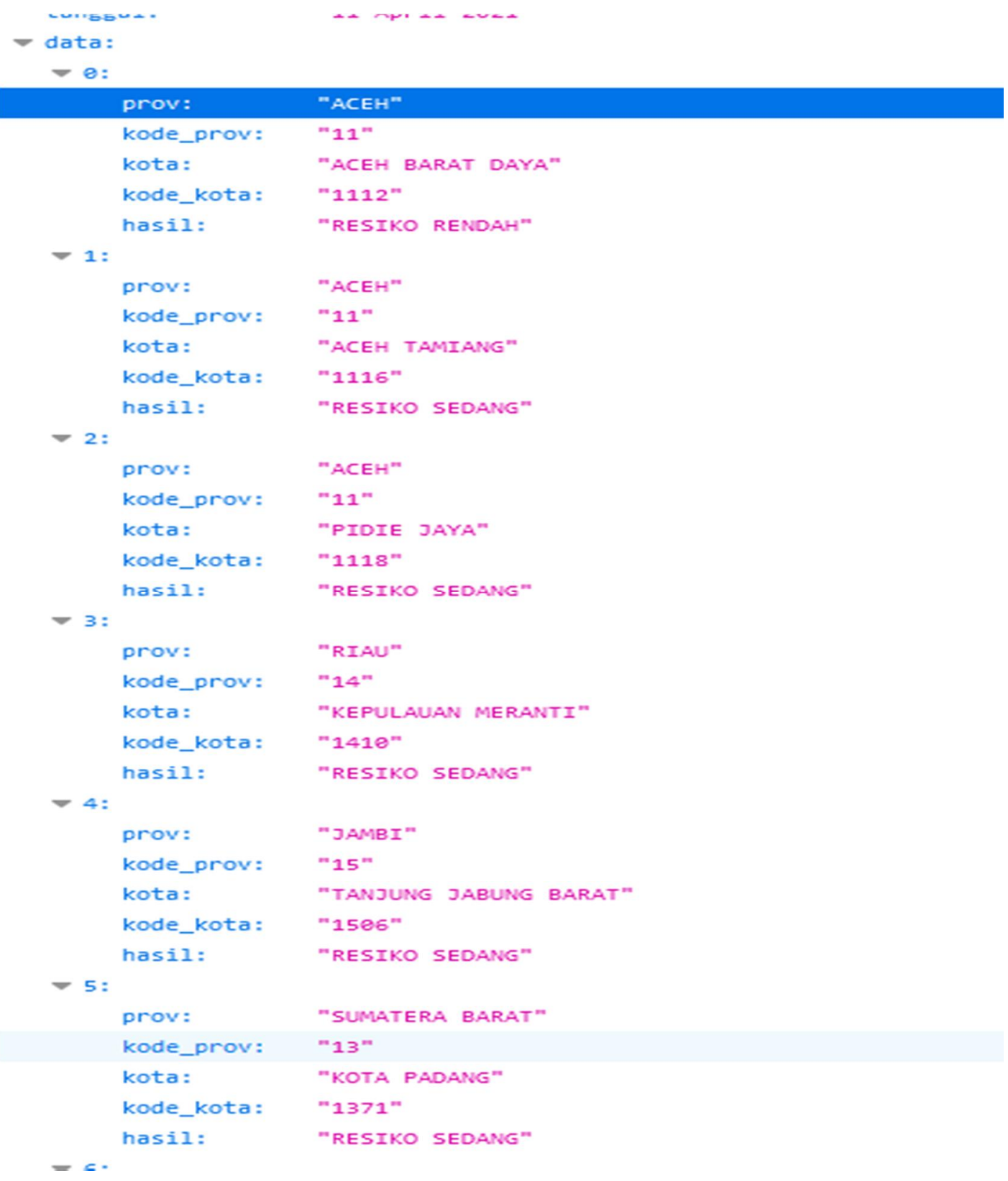

Gambar 2. Json Sebaran Resiko Penularan Covid-19

Fathul, et., al [Implementasi Web Service Pada Sistem Informasi Geografis (SIG) Peta Sebaran Data Covid-19 Berbasis Mobile Apps] 


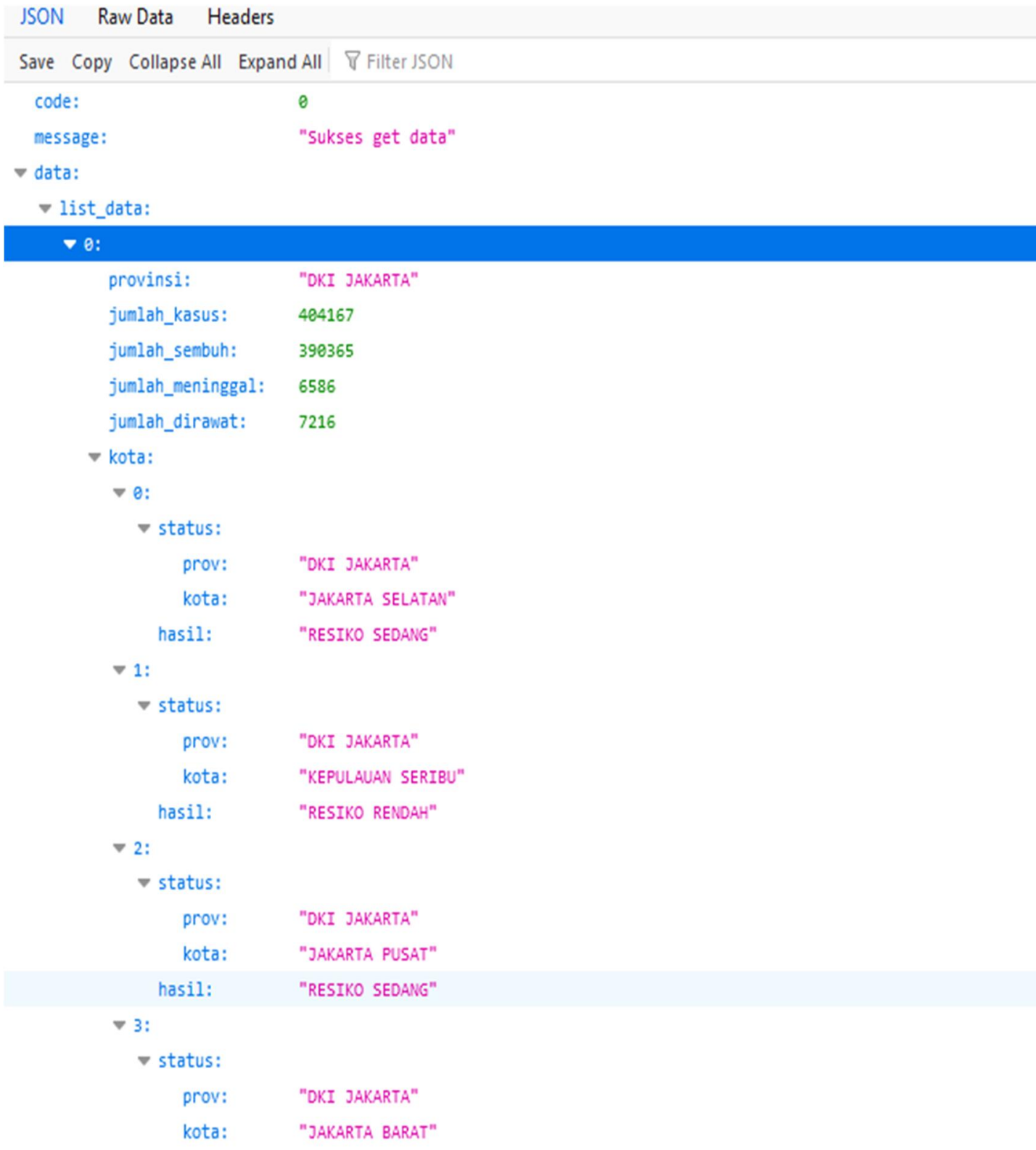

Gambar 3. Json Gabungan Data Covid-19

JavaScript object notation atau yang biasa kita sebut (JSON) merupakan bentuk alterasi informasi yang tidak berat, mudah dibaca serta ditulis oleh orang, dan gampang diterjemahkan serta terbuat (generate) oleh komputer. Format ini terbuat berlandaskan bagian dari Bahasa Pemprograman JavaScript, Standar ECMA- 262 Versi ke- 3- Desember 1999. JSON ialah bentuk bacaan yang tidak tergantung dalam bahasa pemprograman apapun sebab memakai style bahasa yang biasa dipakai oleh programmer keluarga C termasuk C, C++, C\#, Java, JavaScript, Perl, Python dan lain sebagainya [12].

Fathul, et., al [Implementasi Web Service Pada Sistem Informasi Geografis (SIG) Peta Sebaran Data Covid-19 Berbasis Mobile Apps] 


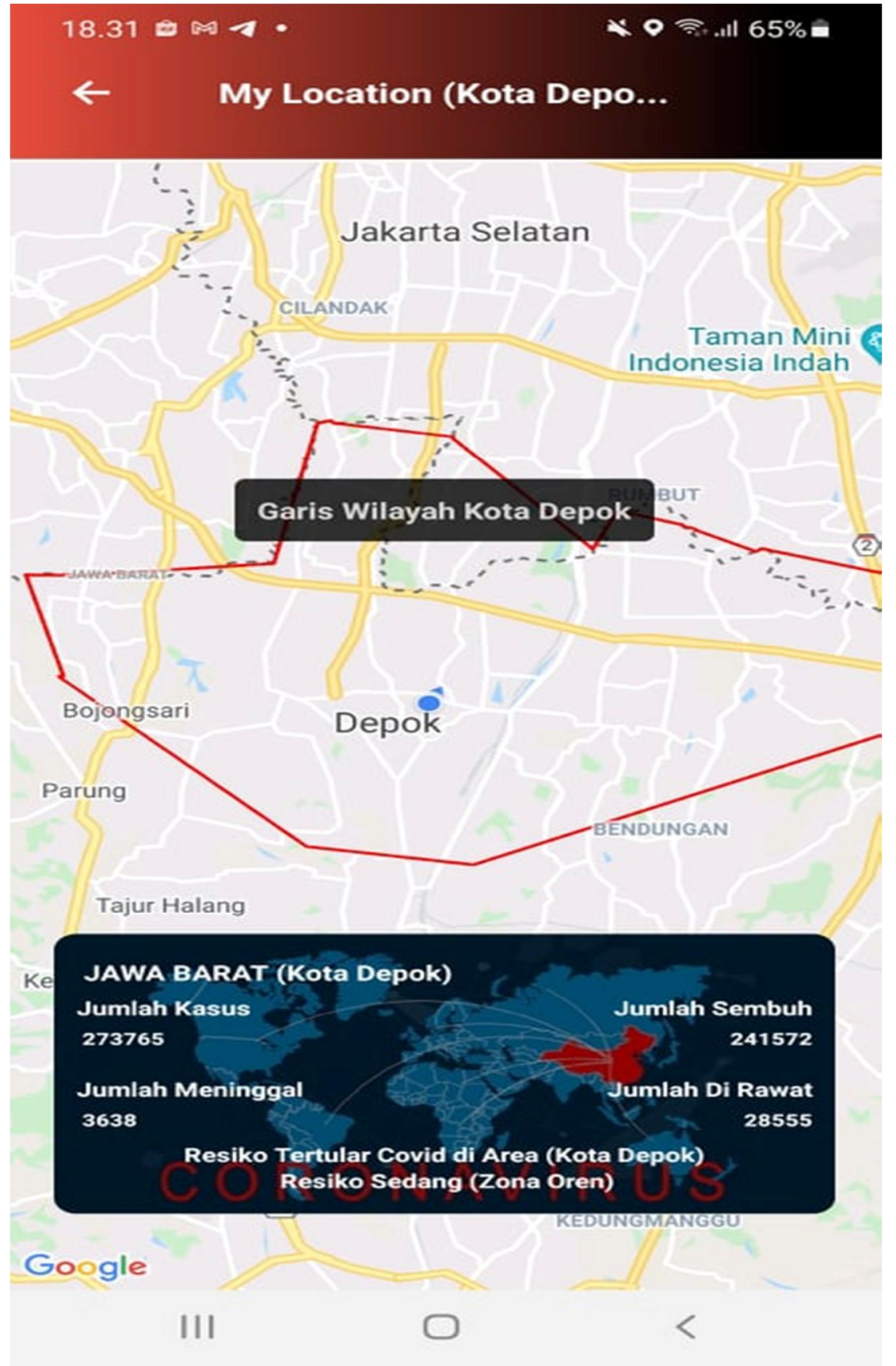

Gambar 4. Visualisasi User Interface (UI)

\subsection{Indentifikasi Kebutuhan Sistem}

Identifikasi kebutuhan sistem pada prose pembuatan sebuah aplikasi mobile apps, (SIG) peta sebaran data covid-19 mulai dari software perangkat lunak (software) serta perangkat keras (hardware). 
Kebutuhan perangkat keras:

- Stroage SSD $128 \mathrm{~GB}$

- Ram $16 \mathrm{~Gb}$

- Processor intel i3

- Kabel data (USB)

- Handphone

Kebutuhan perangkat lunak:

- Nodejs

- SDK (Software Development Kit)

- Hosting

- OS Windows 10

- Web browser

\subsection{Pengujian Sistem}

Dalam tahapan ini aplikasi yang telah selesai kemudian dicoba kelayakannya. Penguji cobaan dilaksanakan beserta memakai 2 metode yaitu:

- Metode black box

- Metode automation testing

- Metode kuesioner

Pemakaian black-box testing dalam menentukan apakah fitur pada aplikasi beroperasi dengan normal seperti seharusnya serta berlangsung dengan baik. Metode black box testing merupakan metode untuk melaksankan sebuah pengujian pada aplikasi perangkat lunak yang telah di buat oleh seorang developer dan dipakai sebagai menguji sebuah perangkat lunak tanpa dikengetahuinya struktur internal kode ataupun program dan memastikan apakah fitur dari aplikasi berjalan secara normal dan lancar. Kelebihan black box adalah dibuat melaksanakan black box testing, tidak menginginkan orang yang mempunyai latar belakang teknis.

Metode ke dua dilakukan dengan menggunakan metode automation testing yaitu metode pengujian dengan menggunakan suatu software testing. Software yang akan di gunakan dalam pengujian aplikasi sistem informasi geografis berbasis mobile ini menggunakan Appium. Appium ini merupakan open-source tool yang dipakai secara khusus dalam mengotomisasi aplikasi mobile, bagaimana apium ini bekerja, berikut di bawah ini adalah gambar 5 cara kerja Appium 


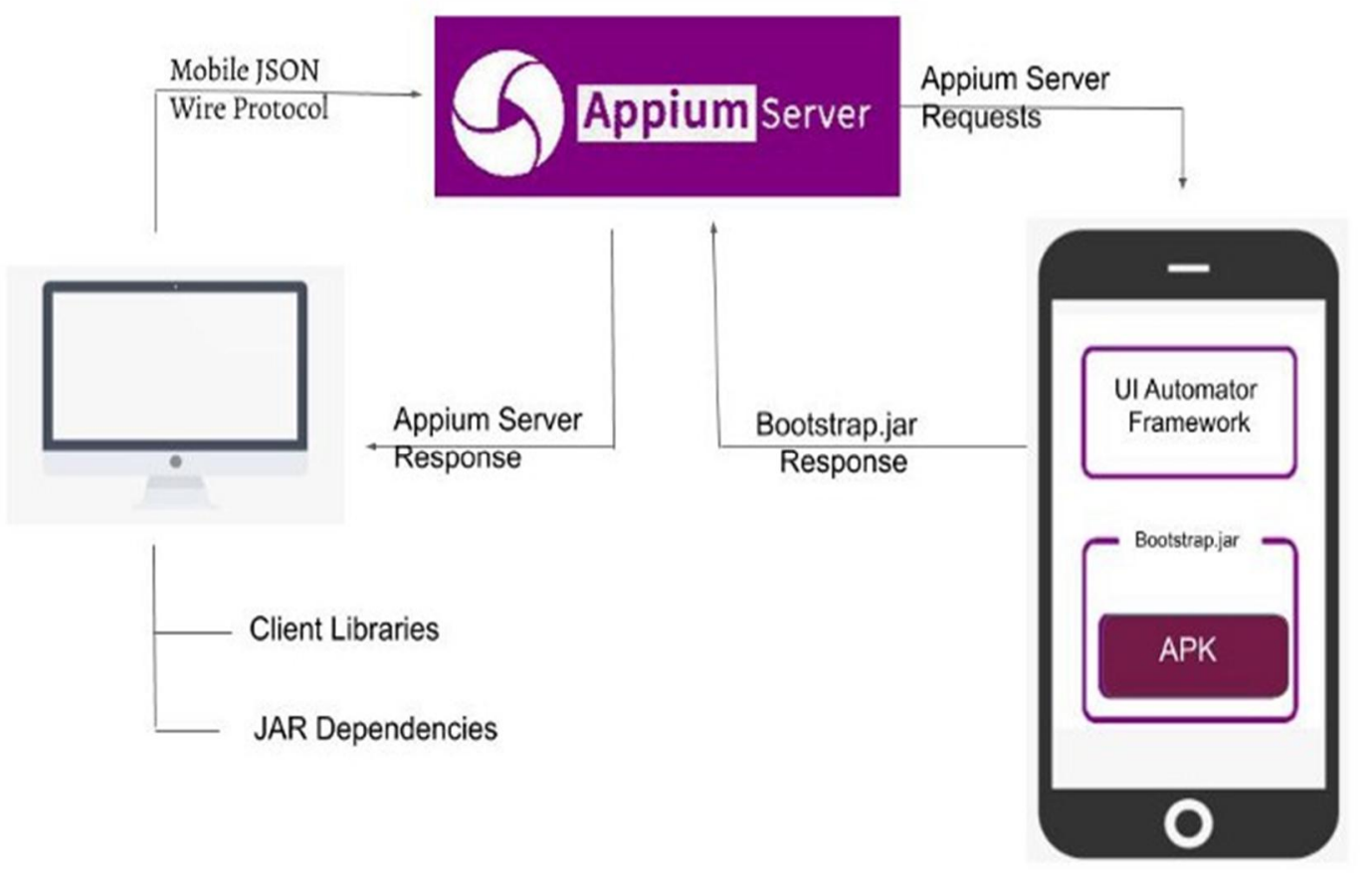

Gambar 5. Cara Kerja Appium

- Library klien mengonversi perintah tertulis pengguna menjadi permintaan REST API.

- Permintaan ini dikirim ke Server Appium menggunakan mobile JSON Wire Protocol

- Server appium meneruskan permintaan ini ke perangkat / emulator android.

- Perintah-perintah ini diinterpretasikan oleh bootstrap.jar yang mengubahnya menjadi format UI Automator yang dapat dimengerti seluler.

- Perintah UI Automator sekarang dijalankan di perangkat / emulator.

- Perangkat / emulator kemudian mengembalikan hasil dari perintah yang dilakukan ke server Appium melalui bootstrap.jar.

- Server appium meneruskan respons ini ke klien.

Kelebihan appium adalah sebuah tools yang bersifat open source untuk menjalankan sebuah script yang telah kita buat dan mengujinya pada aplikasi web seluler, dan aplikasi hibrid di smartphone, tablet, Android dan iOS. Tools ini menggunakan protokol WebDriver sebuah kerangka kerja yang di gunakan untuk mengotomatiskan tugas yang terkati dengan user interface (UI) dan bahasa pemrograman C\#, dan memiliki komunitas pengembang yang kuat di belakangnya.

\subsection{Web Service}

Ada beberapa api yang sudah di buat dalam proses pembuatan sistem informasi geografi sumber di ambil dari covid19.go.id dan situs lainnya, data tersebut di letakan di hosting situs animemusic.us dan kemudian di consume untuk di gunakan di mobile apps. Berikut gambar tampilan respon api yang sudah saya gabungkan dalam bentuk json menggunakan framework Express.

Fathul, et., al [Implementasi Web Service Pada Sistem Informasi Geografis (SIG) Peta Sebaran Data Covid-19 Berbasis Mobile Apps] 

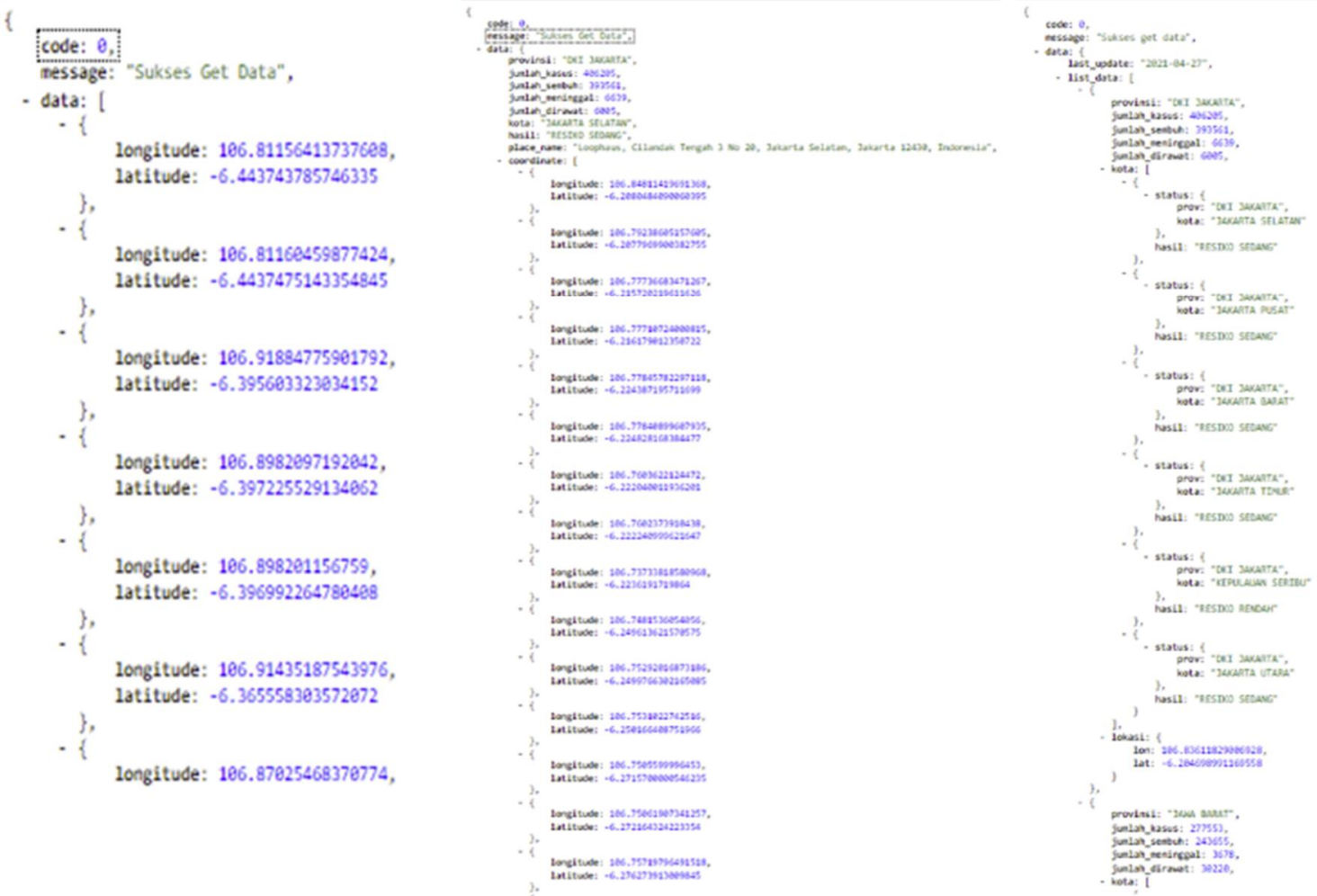

Gambar 6. Tampilan Semua Data Json Covid-19

\subsection{User Interface}

Ada beberapa User interface (UI) yang sudah di buat dalam pembuatan aplikasi sistem informasi geografis (SIG). UI ini sebagai salah satu unsur terpenting dalam user experience (UX). UI melingkupi seluruh bagian konsep visual. UI tidak cuma mengangkat konsep visual hingga estetika. Tetapi pula bisa mempermudah konsumen dalam melaksanakan aplikasi. Oleh sebab itu, UI mempraktikkan rancangan desain visual, desain interaksi, serta arsitektur informasi. Berikut merupakan gambar tampilan design sementara pada aplikasi sistem informasi geografi berbasis mobile.

User interface (UI) merupakan istilah yang dipakai sebagai menggambarkan tampilan mesin atau komputer yang berhubungan langsung dengan para pengguna. Perlu mempertimbangkan desain dan pengaturan antarmuka untuk mendapatkan efek tampilan yang baik [13]. 


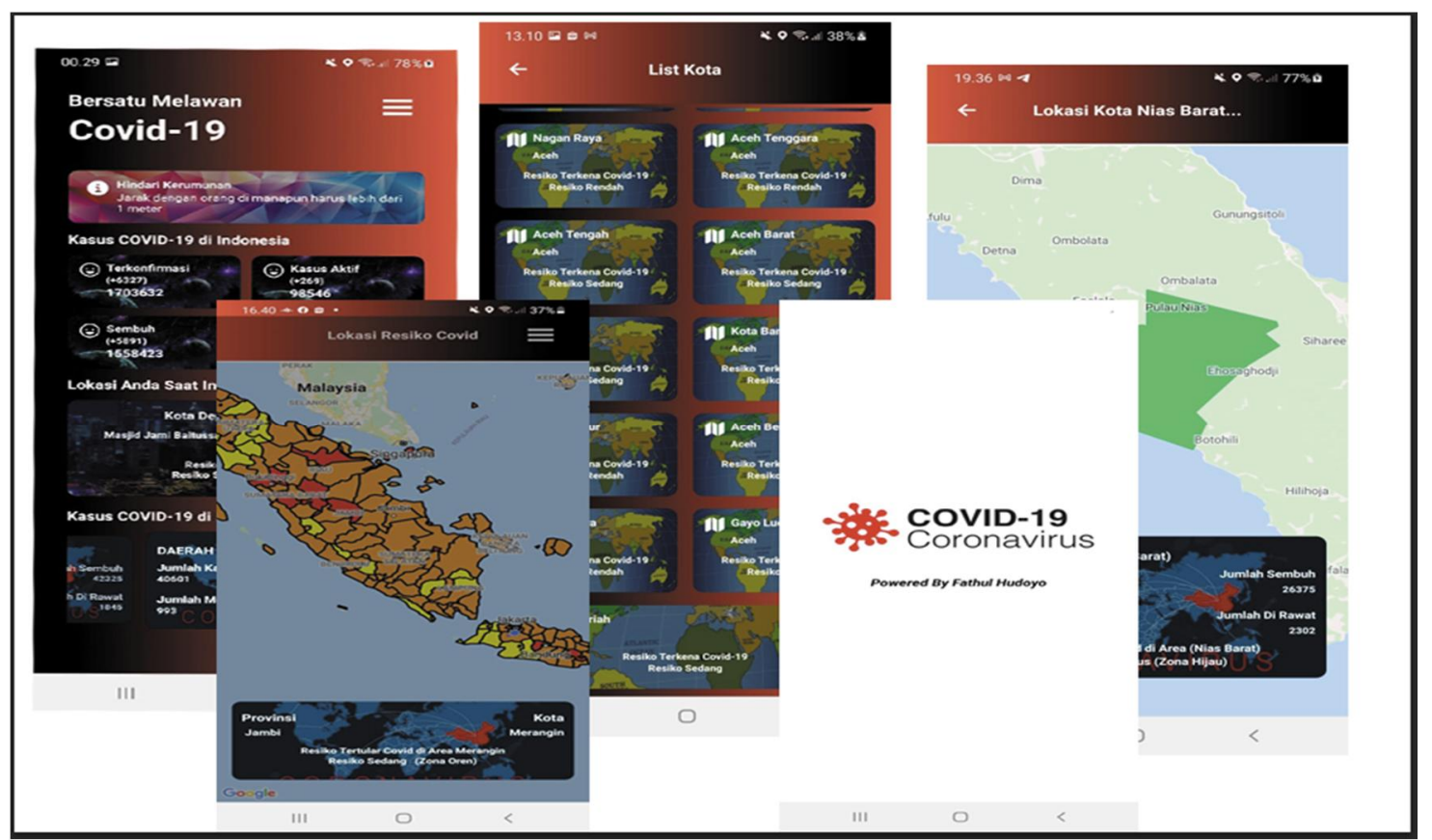

Gambar 7. Tampilan Dashboard dan Splash Screen

\section{HASIL DAN PEMBAHASAN}

Setelah seluruh perancangan hingga pengujian sistem aplikasi mobile apps dilaksanakan, kemudian akan dapatnya hasil aplikasi yang sudah dibangun antara lain:

- Gambar 8 halaman dashboard dan splash screen

- Gambar 9 halaman Tampilan halaman zona lokasi wilayah kota yang terdampak Covid-19 berdasarkan coordinate wilayah dan Halaman list kota bedasarkan provinsi tertentu

- Gambar 10 Halaman M enu dan Halaman Semua Lokasi Zona Yang Terdampak Covid19 


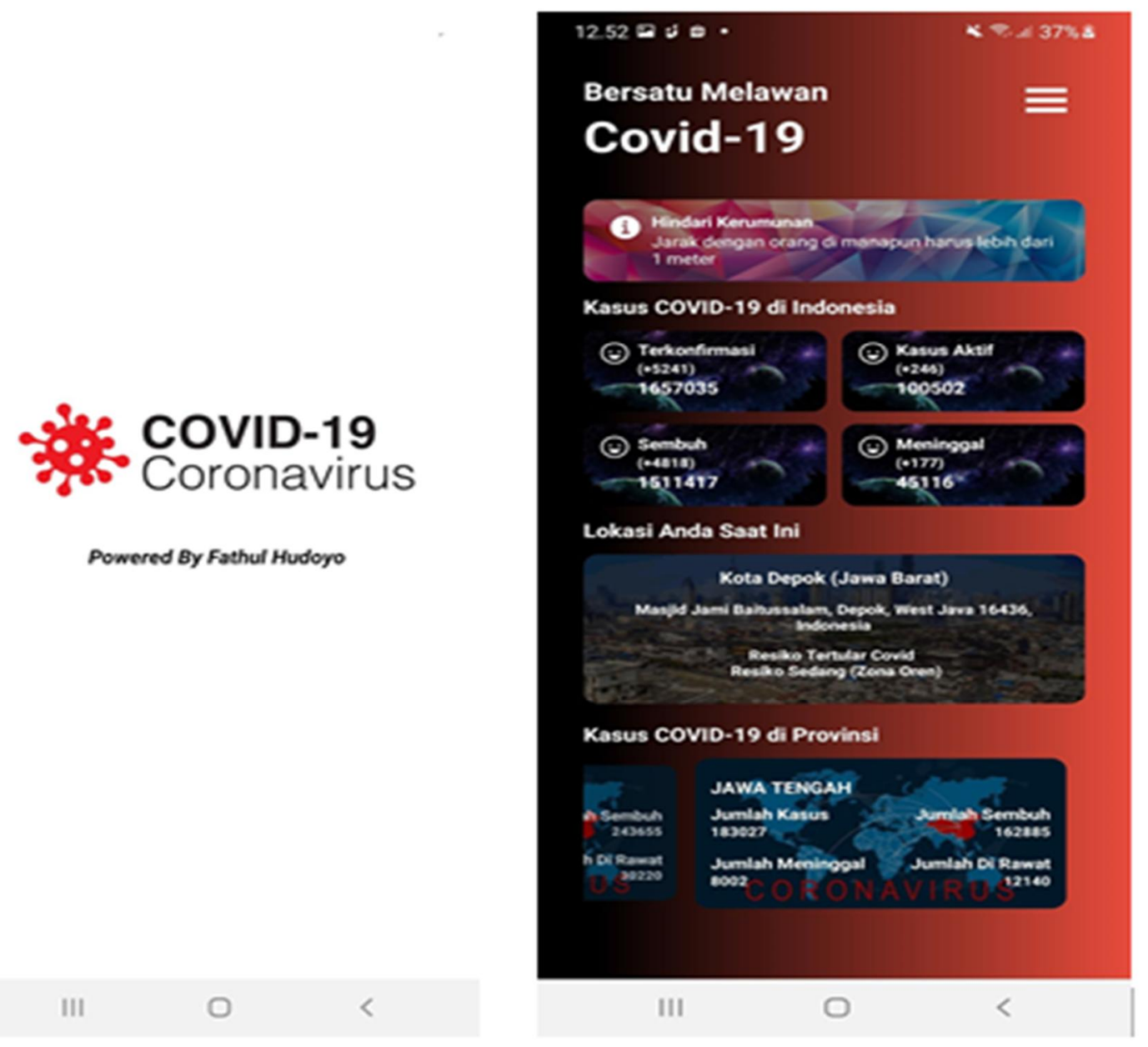

Gambar 8. Tampilan Dashboard dan Splash Screen 

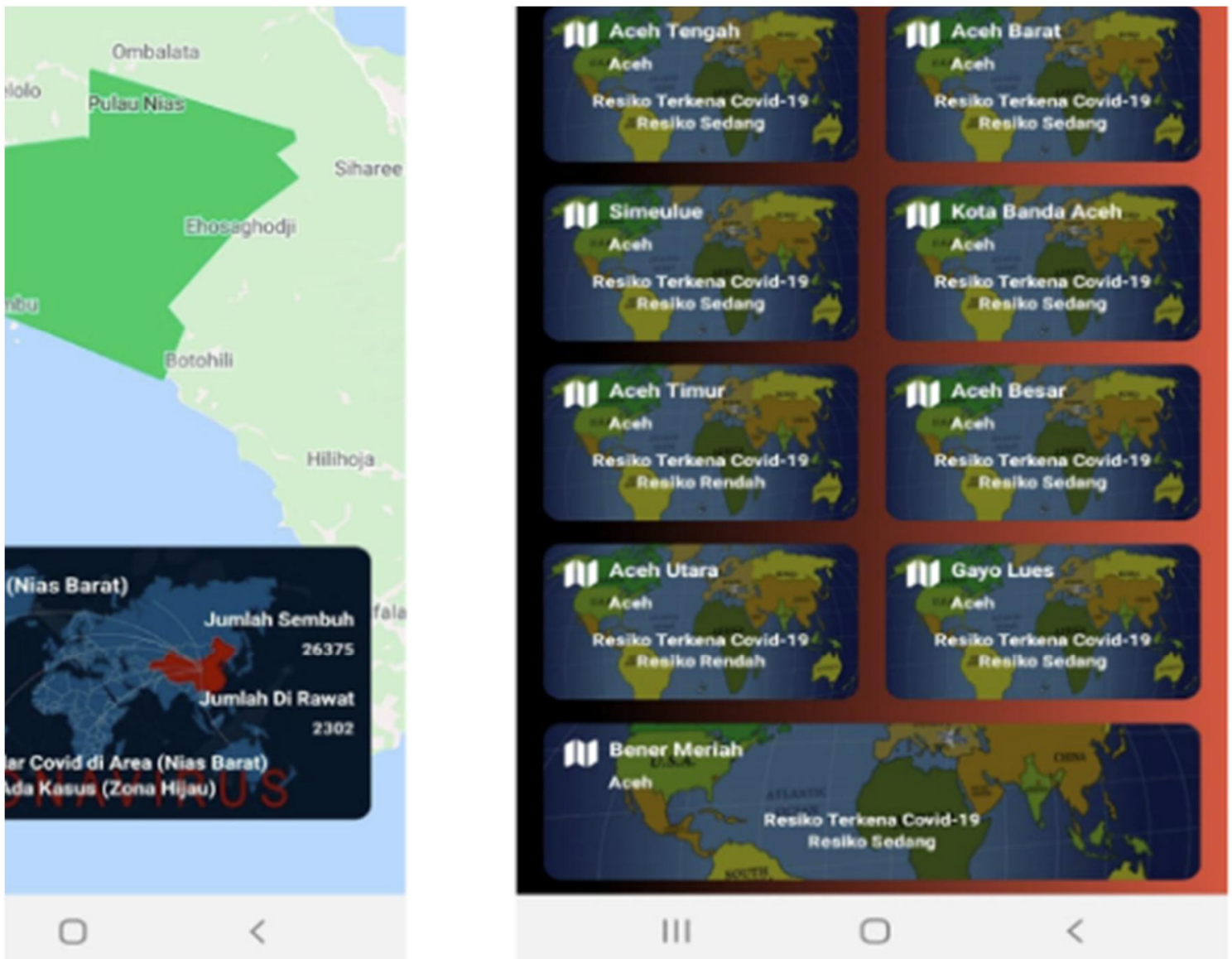

III

Gambar 9. Tampilan Halaman Zona Lokasi Wilayah Kota yang Terdampak Covid-19 Berdasarkan Coordinate Wilayah dan Halaman List Kota Berdasarkan Provinsi Tertentu 


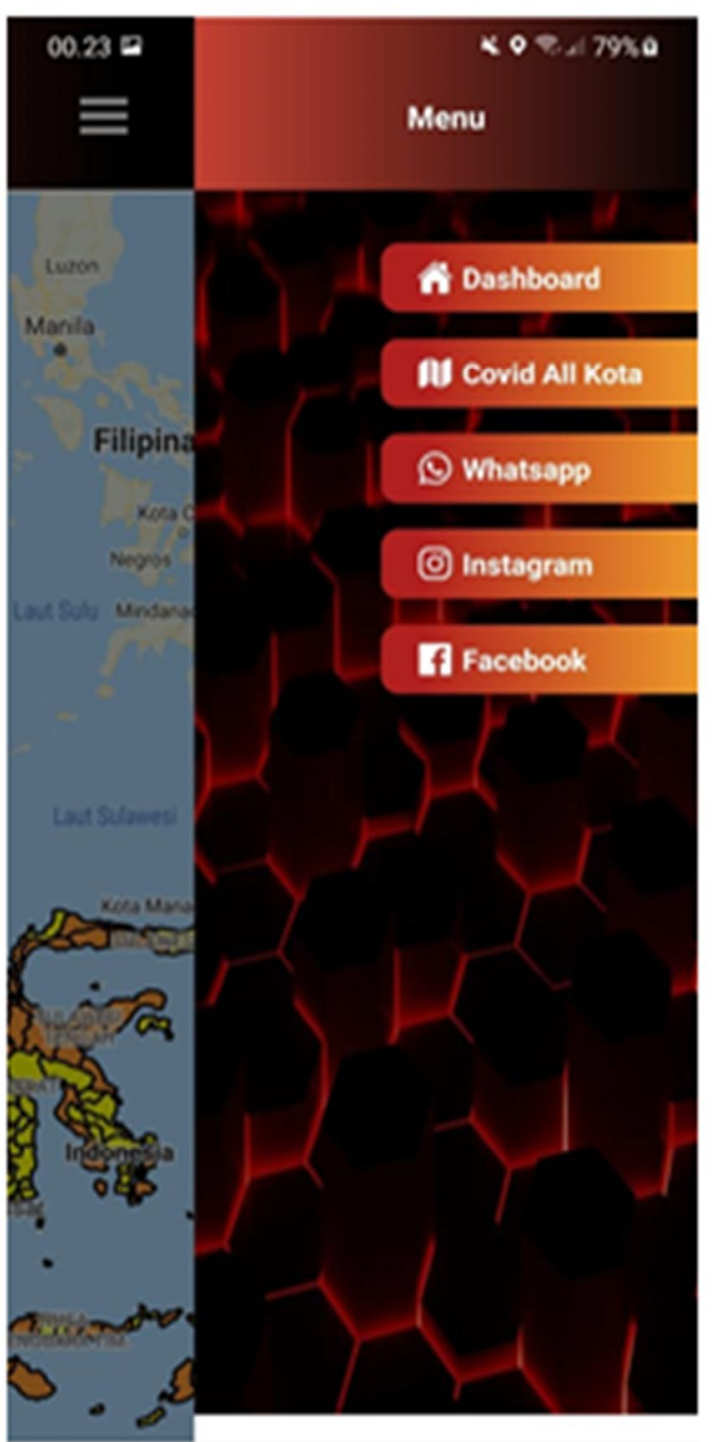

III

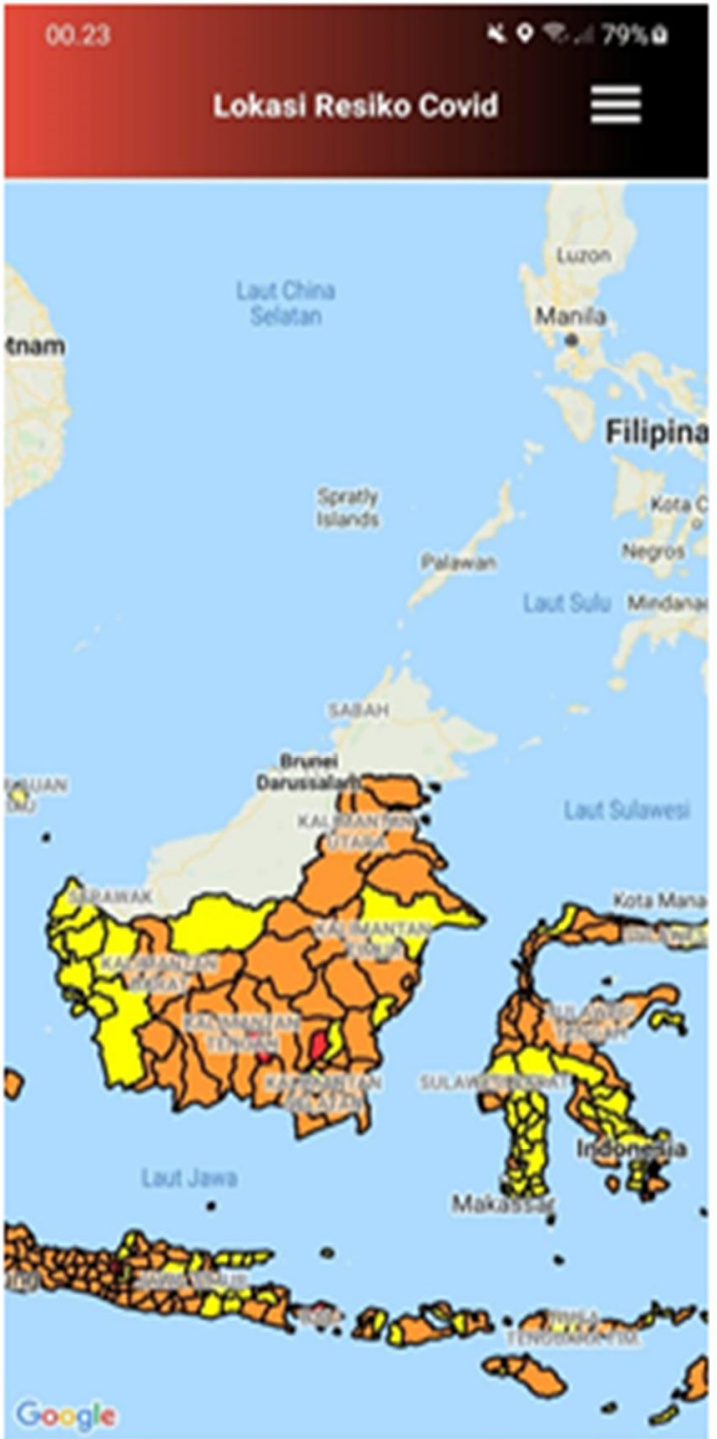

III

Gambar 10. Halaman Menu dan Halaman Semua Lokasi Zona yang Terdampak Covid-19

Pengujian aplikasi (SIG) peta sebaran data covid 19 pada perangkat android dilaksanakan melalui pemakaian metode black box testing, kuesioner, dan automation testing menggunkan Appium. Pada pengujian black box dan automation testing memberitahu bahwa aplikasi telah beroperasi sesuai dengan yang seharusnya. Tidak hanya itu, digunakannya pula metode kuesioner agar mengetahui tanggapan kepuasan pengguna pada aplikasi (SIG) yang sudah diciptakan dapat di lihat pada gambar 11 hasil respon pengguna. Di ketehui pada gambar 11 total responden sebanyak 122 orang, dan pada hasil responden di ketahui fungsional aplikasi $98 \%$ berjalan dengan baik, hasil penilaian tampilan user interface dan user experience dari aplikasi mobile apps terbanyak adalah skala 9, 8 dan 10.

Black-Box Testing merupakan berfokus pada teknologi pengujian perangkat lunak untuk spesifikasi fungsional perangkat lunak, Black-Box Testing bekerja tanpa memikirkan struktur kontrol untuk fokus terhadap informasi domain. Black-Box Testing dimungkinkan

Fathul, et., al [Implementasi Web Service Pada Sistem Informasi Geografis (SIG) Peta Sebaran Data Covid-19 Berbasis Mobile Apps] 
pengembang perangkat lunak untuk membentuk serangkaian kondisi input untuk melatih semua persyaratan fungsional program. Keuntungan menggunakan pengujian black box merupakan penguji tanpa perlu mengetahui bahasa pemrograman yang ditentukan. Pengujian dilaksanakan dari sudut pandang pengguna, yang membantu mengungkapkan ambiguitas atau inkonsistensi pada spesifikasi persyaratan. Pemrogram dan penguji bergantungan satu sama lain [14].

Software testing adalah suatu metode untuk menilai (assess) tingkatan fungsionalitas pada sebuah aplikasi perangkat lunak. Testing juga dipakai untuk menentukan atau meninjau kualitas, kinerja, sebuah suatu aplikasi perangkat lunak sebelum dilakukannya pengimplementasi pada ranah publik (real production). Pertanyaan yang sering muncul ialah mengapa testing sangat dibutuhkan? Padahal dalam metodelogi SDLC tidak banyak yang dibahas mengenai testing [15].
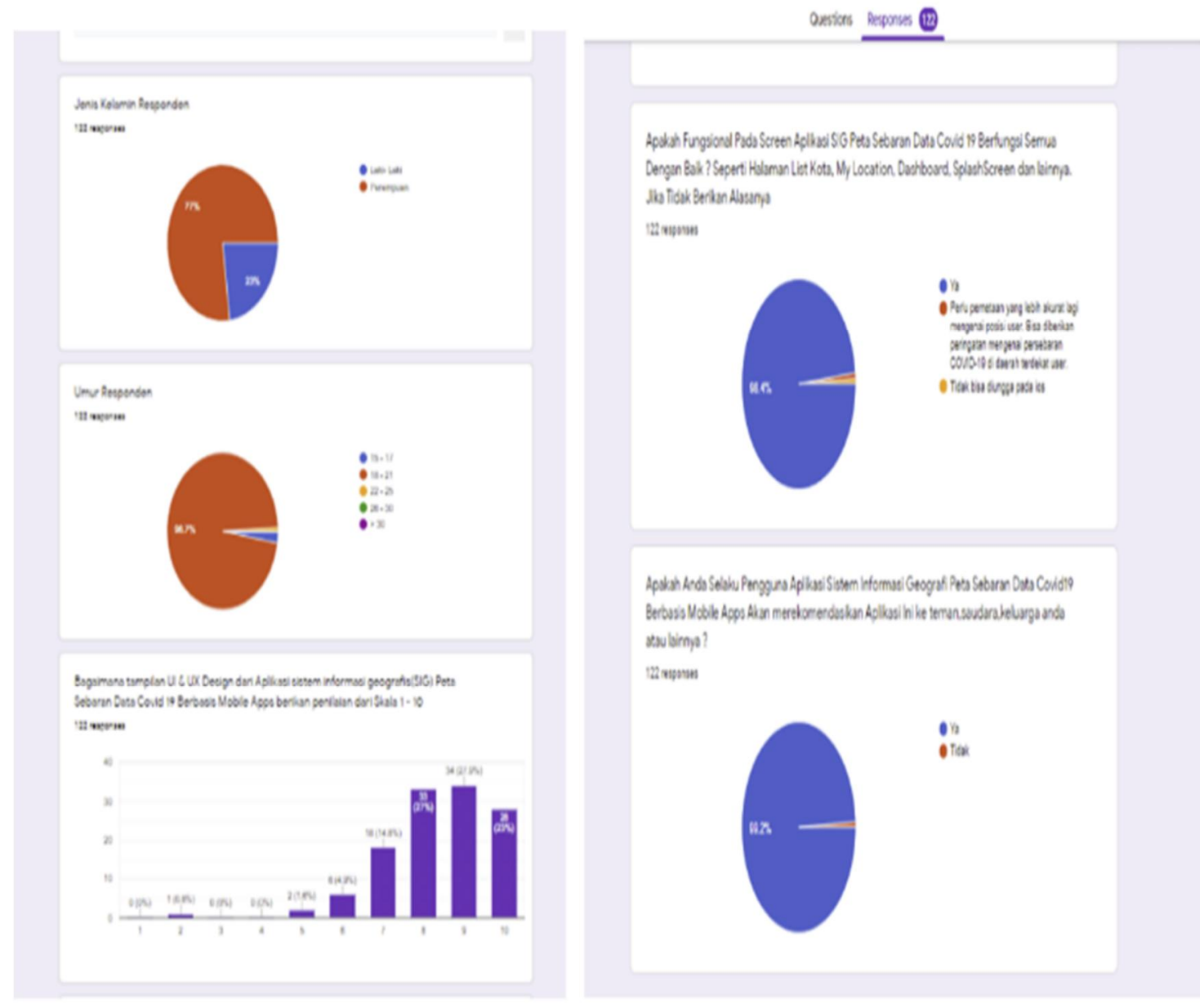

Gambar 11. Hasil Respon Pengguna

\section{KESIMPULAN}

Berdasarkan pembahasan dan pengujian, maka dapat diambil beberapa kesimpulan. Kepuasan pengguna terhadap tampilan dan kemudahan menggunakan aplikasi mobile apps peta

Fathul, et., al [Implementasi Web Service Pada Sistem Informasi Geografis (SIG) Peta Sebaran Data Covid-19 Berbasis Mobile Apps] 
sebaran data covid19 sangat memuaskan terlihat pada kuesioner skala terbanyak adalah 9 dan fungsional pada setiap halaman apps terlihat pada kuesioner $98 \%$ aplikasi berjalan dengan baik. Dengan menggunakan web service maka semua platform aplikasi web maupun apps bisa dengan mudah mengakses resource dan mengabungkan data covid19 dengan data lainnya hanya dengan melalui http request tanpa harus berinteraksi dengan query yang ada pada database.

\section{SARAN}

Sistem yang dibentuk masih mempunyai beberapa kekurangan, dengan demikian ada beberapa hal yang harus dikembangkan untuk menjadi lebih baik, sebagai berikut. Perlunya dapatnya pemberitahuan (notification), Saat kita sedang di jalan dan memasuki zona - zona tertentu seperti hijau, merah, oren, kuning atau lainnya. Pengembangan dari aplikasi Sistem Informasi Geografis (SIG) Peta Sebaran Data Covid-19 diharapkan nantinya bisa beroprasi disemua platform tidak hanya pada smartphone android saja akan tetapi dapat berjalan di ios.

\section{UCAPAN TERIMA KASIH}

Saya selaku penangung jawab peneliti sistem informasi geografis( SIG) mengucapkan banyak- banyak bersyukur kepada tim review, penerbit khususnya para pengajar(dosen) di perguruan tinggi ternama.

\section{DAFTAR PUSTAKA}

[1] A. Nur, A. Thohari, and A. B.Vernandez, 2020, "Aplikasi Monitoring Kasus Coronavirus( Covid-19) Berbasis Android," JTET( Jurnal Tek. Elektro Ter. Polines, Vol. 9, No. 1, pp. 12-17.

[2] D. Y. Prasetyo, 2020, “ Sistem Informasi Monitoring Covid-19 Berbasis Web, ” Juti Unisi, Vol. 4, No. 15, pp. 7-20, [Online]. Available: http://ejournal.unisi.ac.id/index.php/juti/article/view/1400.

[3] F. Al Isfahani, F. Nugraha, R. Mubarok, A. Rahmatulloh, and S. Artikel, 2019. "Informasi Artikel a BSTR a Ct," Vol. 2, No. 1, pp. 33-39.

[4] M. Jamil,Mufti Amir Sultan, and Fera The, 2020, "Sosialisasi Pemanfaatan Aplikasi Corona Tracer Untuk Monitoring Jumlah Kasus Covid 19 pada Mahasiswa Peserta Kuliah Berkarya Bermasyarakat (Kubermas) Universitas Khairun,"JURPIKAT (Jurnal Pengabdi. Kpd. Masyarakat), Vol. 1, No. 3, pp. 234-240, doi: 10.37339/jurpikat.v1i3.320.

[5] R. S. Hendrasari, 2020. "Studi Peningkatan Kebutuhan Air Bersih pada Masa Pandemi Covid 19 di Kota Yogyakarta,” Pros. Semin. Nas. Unimus, Vol. 3, pp. 962-966, , [Online]. Available: http://prosiding.unimus.ac.id. 
[6] L. A. Wardana, 2016, "Perancangan Antarmuka Aplikasi Mobile Konseling pada Gereja Katolik Dengan Metode User Centered Design (UCD) dan Wireframe," S2 Thesis, pp. 17-39, [Online]. Available: http://eprints.stainkudus.ac.id/192/5/5. BAB II.pdf.

[7] D. E. Sondakh, S. R. Pungus, P.Runtukahu, and R.Saroinsong, 2016, "Implementasi Teknologi Web Services pada Aplikasi Pencarian Taxi," CogITo Smart J., Vol. 2, No.1, p. 1, doi: 10.31154/cogito.v2i1.10.1-13.

[8] Y. Makasudede, 1953. "Bab 2 Tinjauan Pustaka," pp. 8-45,

[9]Ｋ. Ge. F, 1967, “済無No Title,” Angew. Chemie Int. Ed. 6(11), 951-952, pp. 16-74,.

[10] S. S. Putra, G.Susilo, and C. Sundari, 2019. "Sistem Informasi Geografis Pemetaan Lahan Pertanian Tembakau di Kecamatan Kledung, Kabupaten Temanggung,"J. Transform. (Informasi Pengemb.Iptek),vol. 15, no. 2, pp. 97-105,

[11] B. Adi Pranata, A. Hijriani, and A. Junaidi, 2018, "Perancangan Application Programming Interface (Api) Berbasis Web Menggunakan Gaya Arsitektur Representational State Transfer (Rest) Untuk Pengembangan Sistem Informasi Administrasi Pasien Klinik Perawatan Kulit,” J. Komputasi, Vol. 6, No. 1, pp. 33-42, doi: 10.23960/komputasi.v6i1.1554.

[12] Y. Herdiana, 2014. “Aplikasi Rumus Matematika Sma Berbasis Mobile," J. Ilm. Komput. dan Inform.( KOMPUTA ),

[13] M. N. El Ghiffary, T. D. Susanto, and A. H. Prabowo, 2018, "Analisis Komponen Desain Layout, Warna, dan Kontrol pada Antarmuka Pengguna Aplikasi Mobile Berdasarkan Kemudahan Penggunaan (Studi Kasus: Aplikasi Olride)," J. Tek. ITS, Vol. 7, No. 1, doi: 10.12962/j23373539.v7i1.28723.

[14] T. S. Jaya, 2018, "Pengujian Aplikasi Dengan Metode Blackbox Testing Boundary Value Analysis (Studi Kasus: Kantor Digital Politeknik Negeri Lampung)," J. Inform. J. Pengemb. IT, Vol. 3, No. 2, pp. 45-48, doi: 10.30591/jpit.v3i1.647.

[15] H. Mantik, 2014, "Peran Penting Testing Dan Quality Assurance Dalam Siklus Pengembangan Sistem," J. Sist. Inf. Univ. Suryadarma, Vol. 4, No. 2, pp. 75-79, doi: 10.35968/jsi.v4i2.7. 